\title{
Two new species of Cirratulidae (Annelida: Polychaeta) from Mar del Plata, Argentina (SW Atlantic)
}

\author{
RODOLFO ELÍAS ${ }^{1}$ \& MARÍA SILVIA RIVERO \\ Laboratorio de Bioindicadores Bentónicos. Departamento de Ciencias Marinas, Universidad Nacional de Mar del Plata. Deán Funes \\ 3350. B 7602 - AYL. Mar del Plata, Argentina. \\ ${ }^{\text {l} C o r r e s p o n d i n g ~ a u t h o r . E-m a i l: ~ r o e l i a s @ m d p . e d u . a r ~}$
}

\begin{abstract}
Cirratulidae from Mar del Plata $\left(38^{\circ} \mathrm{S}, 57^{\circ} \mathrm{W}\right)$ are under revision. The city has an intertidal outfall, and several polychaetes are associated with both intertidal and subtidal communities in organically enriched areas. The present paper provides the first records of the cirratulid genera Protocirrineris and Aphelochaeta from Argentine waters: $P$. angelicollatio sp. nov. from intertidal areas and A. malefica sp. nov. from shallow subtidal areas. Living specimens of $P$. angelicollatio sp. nov. were observed and asexual reproduction and high regeneration rates have been observed.
\end{abstract}

\section{Resumen}

Los Cirratulidae de los alrededores de Mar del Plata $\left(38^{\circ} \mathrm{S}, 57^{\circ} \mathrm{W}\right)$ están siendo revisados. La ciudad posee un efluente intermareal, y varias especies de poliquetos se hallan asociados a las comunidades bentónicas inter y submareales enriquecidas orgánicamente. Los géneros Protocirrineris y Aphelochaeta son mencionados por primera vez para aguas argentinas, $P$. angelicollatio sp. nov. es descripta para áreas intermareales, y A. malefica sp. nov. para fondos someros, ambos ambientes orgánicamente enriquecidos. Especimenes vivos de $P$. angelicollatio sp. nov. se hallan bajo observación, y altos ritmos de regeneración y reproducción asexual han sido observados.

Key words: Protocirrineris, Aphelochaeta, taxonomy, intertidal, subtidal, organically enriched areas, Mar del Plata, Argentina

\section{Introduction}

Argentina has 4,000 $\mathrm{km}$ of coast and nearly $1,000,000 \mathrm{~km}^{2}$ of continental shelf. The region has several oceanographic features including the front of the Rio de la Plata estuary, the shelf-break front, and tidal fronts (Acha et al. 2004). Due to the confluence of two major currents, the Brazil (warm-temperate) and Malvinas (subantarctic), two Zoogeographic Provinces occur along the coast (Boschi 2000). An unpublished list of cirratulids is available for the southern Argentina (the Magellanic Province, Orensanz 1974), but there are no records of cirratulids for the northern area. Mar del Plata $\left(38^{\circ} \mathrm{S}, 57^{\circ} \mathrm{W}\right)$ is in the northern warm-temperate Argentine Zoogeographical Province, which extends from southern Brazil to northern Argentina. 
In some respects, most Latin American environments are largely unexplored and the marine flora and fauna, especially the polychaetes, are poorly known. Only a few biologists work on polychaete taxonomy, and this is usually as a secondary task, because ecological assessment is the main source of financial support and human resources formation. One of the most poorly known of the polychaetes families is the Cirratulidae, largely due to the lack of taxonomic expertise and poor definition of characters. However recent contributions have reviewed Chaetozone and Caulleriella from the United States (Doner \& Blake 2006) and Costa Rica (Dean \& Blake 2007).

Cirratulidae are common and widespread in soft sediments, but they rarely dominate those communities. The family Cirratulidae includes organisms with a cylindrical body, a blunt or conical prostomium, pairs or multiple sets of dorsal tentacles, and reduced parapodia. Slender filiform branchiae are present on at least the anterior chaetigers. Chaetae include smooth or denticulate capillaries, curved spines, and bidentate hooks; excavate hooks are characteristic of some genera (Fauchald 1977). The distribution and morphology of chaetae is a diagnostic character at the generic and specific level (Blake 1991, 1996; Doner \& Blake 2006; Dean \& Blake 2007), but these features may also depend on age or development of the organism (George \& Petersen 1991).

In intertidal areas affected by sewage discharge off Mar del Plata, cirratulids are frequently encountered and abundant in areas of organic enrichment (Elías et al. 2003, 2006). Other cirratulid species are abundant in subtidal sand patches near the sewage outfall (Elías et al. 2005) and in the harbor (Rivero et al. 2005). In order to understand the role of cirratulids in areas of organic enrichment, we are initiating a study of Argentinian cirratulids. It is well known that polychaete communities are useful for assessing human impact (Pocklington and Wells 1992, Rivero et al. 2005, Giangrande et al. 2005). In the present study two new species belong to the genera Aphelochaeta and Protocirrineris are described from organically enriched areas.

\section{Materials and methods}

Subtidal samples from sand bottoms off a sewage outfall were collected with replicate van Veen grabs $\left(0.05 \mathrm{~m}^{2}\right)$ and sieved through a 0.5-mm-mesh sieve (ARA Luisito cruises) (Elías et al. 2004; Elías et al. 2005). Intertidal sampling was carried out in mussel beds of Brachidontes rodriguezii, which is present around sewage outfalls and control sites. Several stations have been sampled since 1997 with replicate $78 \mathrm{~cm}^{2}$ corers and sieved through a 1-mm-mesh sieve (Vallarino et al. 2002; Elias et al. 2003, 2006).

Material was examined with light microscopy and also the Scanning Electron Microscope (SEM) JEOL, JSM - $6460 \mathrm{LV}$. The material for SEM was prepared by fixation for $24 \mathrm{~h}$ with $3 \%$ Glutaraldehyde buffered with sodium cacolitate $(0.1 \mathrm{~mol}$ with a $\mathrm{pH}$ between 7.2 and 7.4$)$, followed by de-hydration though an alcohol series $(50,70,80,90,95$ and $100 \%)$. The sample was dried in HMDS (hexamethyldisilazane), mounted in aluminum discs, and coated with gold-palladium. For small worms, the material was mounted on slides with a Grey \& Wess Medium (PVA) for optical observation.

Type material was deposited in the Museo de Ciencias Naturales (MLP) of La Plata, Argentina. 


\section{Results}

Genus Aphelochaeta Blake, 1991

Type species Tharyx monilaris Hartman, 1960, designated by Blake 1991.

Diagnosis. Prostomium conical; peristomium elongate, with pair of grooved dorsal tentacles arising either on or anterior to chaetiger 1; abdominal segments frequently beaded in appearance; chaetae simple capillaries, lacking distinct serrations or sawtooth edge; moniliform segments present or absent; posterior end frequently expanded.

Remarks. The "smooth" or "simple" capillaries of Aphelochaeta viewed with light microscopy are often observed to have fine serrations or distinct fibrils along the edges of the blades when imaged with SEM (see below for A. malefica sp. nov.). These observations complicate the definitions of Aphelochaeta and Monticellina and suggest that neither genus is monophyletic. This topic is further discussed by Dean \& Blake (2009) and Doner \& Blake (2009).

Aphelochaeta malefica sp. nov.

Figure 1 A-E

Caulleriella sp.: Elías et al. 2004: 1178-1179, fig. 3, table 2.

Material examined. Off Mar del Plata, Argentina. Holotype: Sta. 41, 3757.16' S, 57²9.30' W, 12.5 m, black mud, ARA Luisito cruises, August 1999 (1 complete specimen, MLP no 6449). Paratypes: same sample (9 incomplete specimens, MLP $n^{\circ}$ 6450). Other material examined: 15 paratypes from the same sample examined with SEM.

Description. A moderate-size species. Holotype $13 \mathrm{~mm}$ long, $0.4 \mathrm{~mm}$ wide for 86 chaetigers. Thoracic region narrow, not expanded, with 20-25 anterior chaetigers (16 chaetigers in holotype), individual segments about one-third as narrow as abdominal segments; dorsum of thorax forming a crest between lateral grooves above parapodia with parapodia forming shoulders formed by dorsolateral grooves and distinct ventral groove (Fig. 1A-B, D); middle region of body enlarged, with rounded segments, but moniliform, posterior segments narrowing, then expanding dorsally with a terminal pygidium and dorsal anus (Fig. 1C). Color in alcohol light tan or brown.

Prostomium triangular, pointed on anterior margin (Fig. 1A-B, D); eyes absent; peristomium triannulated, inflated, with dorsal crest extending over chaetiger 1; dorsal tentacles extending onehalf length of body, arising medially between peristomial crest and chaetiger 2 (Fig. 1A-B). First pair of branchiae arising lateral to and anterior to dorsal tentacles on chaetiger 1 (Fig. 1B); subsequent branchiae arising dorsal to notochaetal fascicles, then continuing with some arrangement on each anterior segment (Fig. 1B); in middle segments branchiae few, irregularly distributed.

Parapodia well developed anteriorly, bearing dense fascicles of long capillary chaetae. Noto- and neurochaetae in close proximity all along the body. Capillary chaetae long, with fine serrations seen only with SEM (Fig. 1E); fascicles with 5-6 pairs of capillaries in noto- and neuropodia, decreasing from chaetiger 16 to three pairs of capillaries in posterior segments.

Methyl green staining pattern. The prostomium and peristomium stain pale green, while palps and branchiae stain darker.

Habitat. Subtidal, in poorly sorted sands, 12-15 m, off Mar del Plata sewage outfall. 


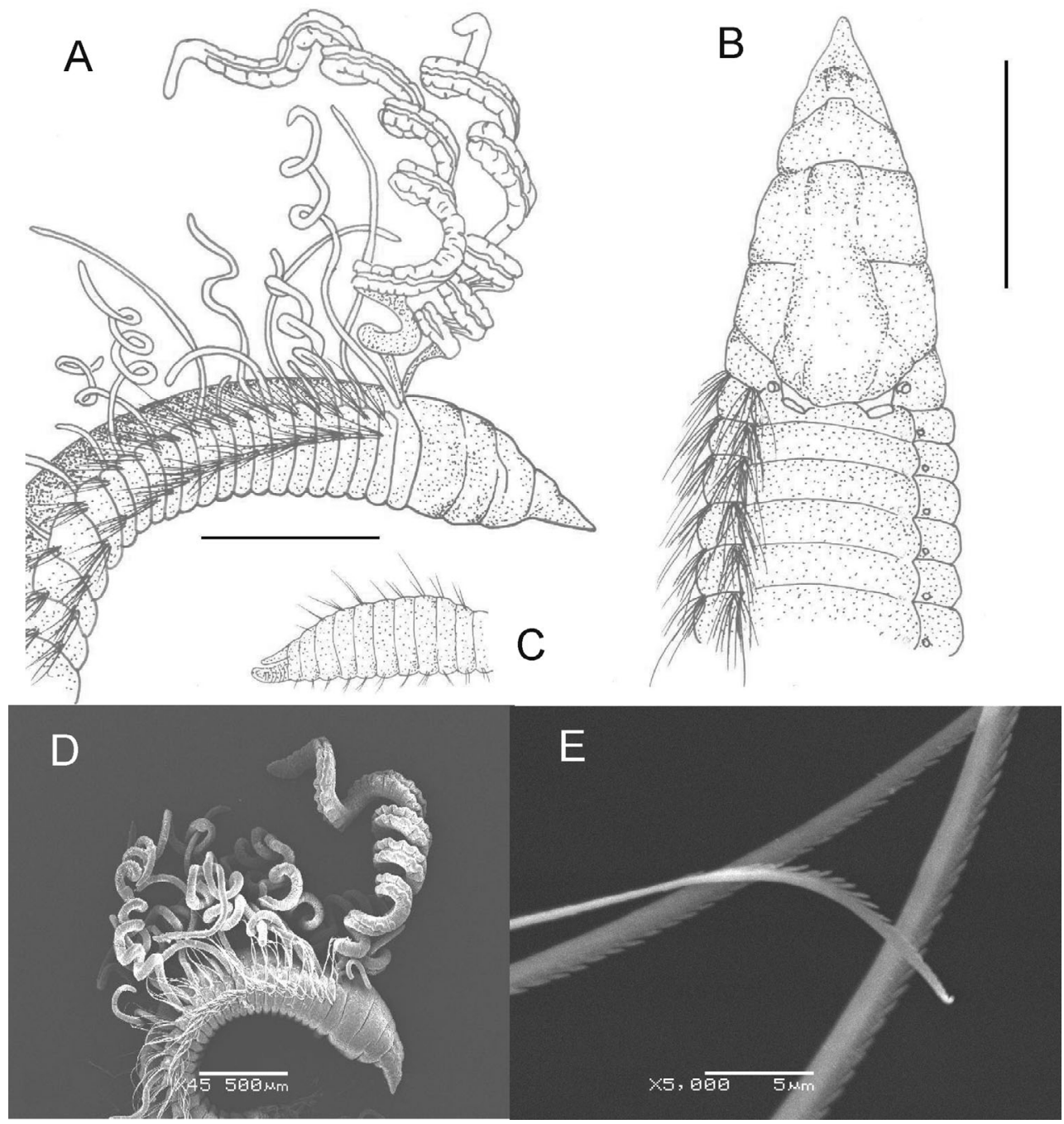

FIGURE 1. Aphelochaeta malefica sp. nov. A, general view of anterior region; B, dorsal view of anterior end; C, pygidium; D, SEM photo of anterior end; E, SEM photo of capillary chaetae. Scale bars: A, C = $0.4 \mathrm{~mm}, \mathrm{~B}=0.2$ $\mathrm{mm}$.

Remarks. Aphelochaeta malefica sp. nov. is characterized by a dorsal peristomial crest that overlaps chaetiger 1, crowded anterior chaetigers, lateral parapodial shoulders offset from the body by paired dorsolateral grooves, and a ventral groove. The far posterior chaetigers are dorsally inflated and bear a dorsal anus. A. malefica sp. nov. is similar to Aphelochaeta glandaria Blake, 1996 in prostomial shape, and by having a peristomium with 2-3 annulations that are dorsally inflated forming a crest; however the crest is at the end of the peristomium in A. glandaria, whereas it extends over chaetiger 1 in A. malefica sp. nov. In addition, A. glandaria has expanded thoracic chaetigers with characteristic ventral glands in the ventrum, dorsal grooves in anterior and middle 
chaetigers, and a ventral groove in middle and posterior chaetigers. A. malefica sp. nov. is similar in body shape to A. tigrina Blake, 1996 especially with the extension of the peristomial crest; however, posterior laterally expanded chaetigers with grooves are lacking in A. malefica sp. nov.

Etymology. The species is named to honor Dr. Paulo Lana, who considers these worms "bichos do mal" (evil bugs) due to their strange and variable chaetal pattern along the body and throughout life.

\section{Genus Protocirrineris Czerniavsky, 1881}

Type species Cirratulus tenuisetis Grube, 1860, designated by Hartman, 1959.

Diagnosis. Prostomium bluntly conical to wedge-shaped, with or without eyes. Body nearly round in cross section, with distinct segments. Grooved tentacular filaments few, arising singly or in paired groups on several anterior chaetigers following chaetiger 1; individual tentacular filaments often arranged in longitudinal rows. Branchiae occurring singly, usually first present from segments with tentacular filaments, sometime on more anterior chaetigers. Chaetae all capillaries. This genus was resurrected and partially redefined by Petersen (1991). A full definition of the genus was provided by Blake (1996).

\section{Protocirrineris angelicollatio sp. nov.}

Figure $2 \mathrm{~A}-\mathrm{F}$

Cirratulus cirratus: Elías et al., 2002: 4, figs. 11-12; Elías et al., 2003: 313-316, table 1, figs. 5-6. (Not Müller, 1776).

Cirratulus sp.: Elías et al. 2006: 191-193, 195, tables 2-3, figs. 6-7.

Material examined. Mar del Plata, Argentina. Holotype: Sta. 2, $200 \mathrm{~m}$ from the source of the sewage outfall, $37^{\circ} 55.591^{\prime} \mathrm{S}, 57^{\circ} 31.701^{\prime} \mathrm{W}$, intertidal limestone among mussels, June 1998 (1 complete specimen, MCNLP $n^{\circ}$ 6451). Paratypes: Sta. 2, intertidal limestone among mussels, February 1998 ( 1 complete specimen and 2 regenerating posterior ends), Sta. 2, intertidal limestone among mussels, June 1998 ( 7 complete specimens and 3 regenerating both extremes, MLP ${ }^{\circ}$ 6452), Sta. 1, $50 \mathrm{~m}$ off sewage outfall, intertidal limestone among mussels, November 2000 (4 complete specimens), Sta. 4, at $750 \mathrm{~m}$ from sewage outfall, intertidal limestone among mussels, November 1998 (3 regenerating posterior ends), Vallarino, E. A., Elías, R. \& Rivero, M. S. col.

Description. A moderate to large species, holotype $18 \mathrm{~mm}$ long, and $1.08 \mathrm{~mm}$ wide anteriorly, decreasing to $0.46 \mathrm{~mm}$ wide in middle and posterior segments for 172 chaetigers. Longer specimens with up to 250 chaetigers. Body quadrangular in cross-section anteriorly, chaetigers 7-8 to approximately chaetiger 25 with dorsal elevated dome; middle and posterior region cylindrical; ventrum flattened along body. Color light brown or yellowish in life, with posterior region pale; edges of the pygidium darkly pigmented. After preservation in formalin specimens becoming dark brown or almost black, including branchiae and tentacular cirri (these paler than branchiae); this coloration retained in alcohol.

Prostomium rounded, short, without eyes. Under SEM a small pair of vertical nuchal slits observed on both sides of prostomium (Fig. 2B). Peristomium with a smooth, low dorsal crest extending posteriorly to chaetiger 2 (Fig. 2C); with two visible annulations dorsally and laterally (Fig. 2A, C), but only laterally in holotype; three annulations visible ventrally; each of three 
annulations increasing in width and depth from anterior to posterior with last peristomial annulation widest; ventrally, third annulation forming a lappet almost completely covering first annulation. Dorsally peristomium of paratypes with 3-4 subannulations in the anterior and 4-5 in the posterior under SEM, the buccal segment also with two annulations (Fig. 2C). Inside mouth a fleshy tubular formation observed in some paratypes and SEM material may represent an eversible pharynx.
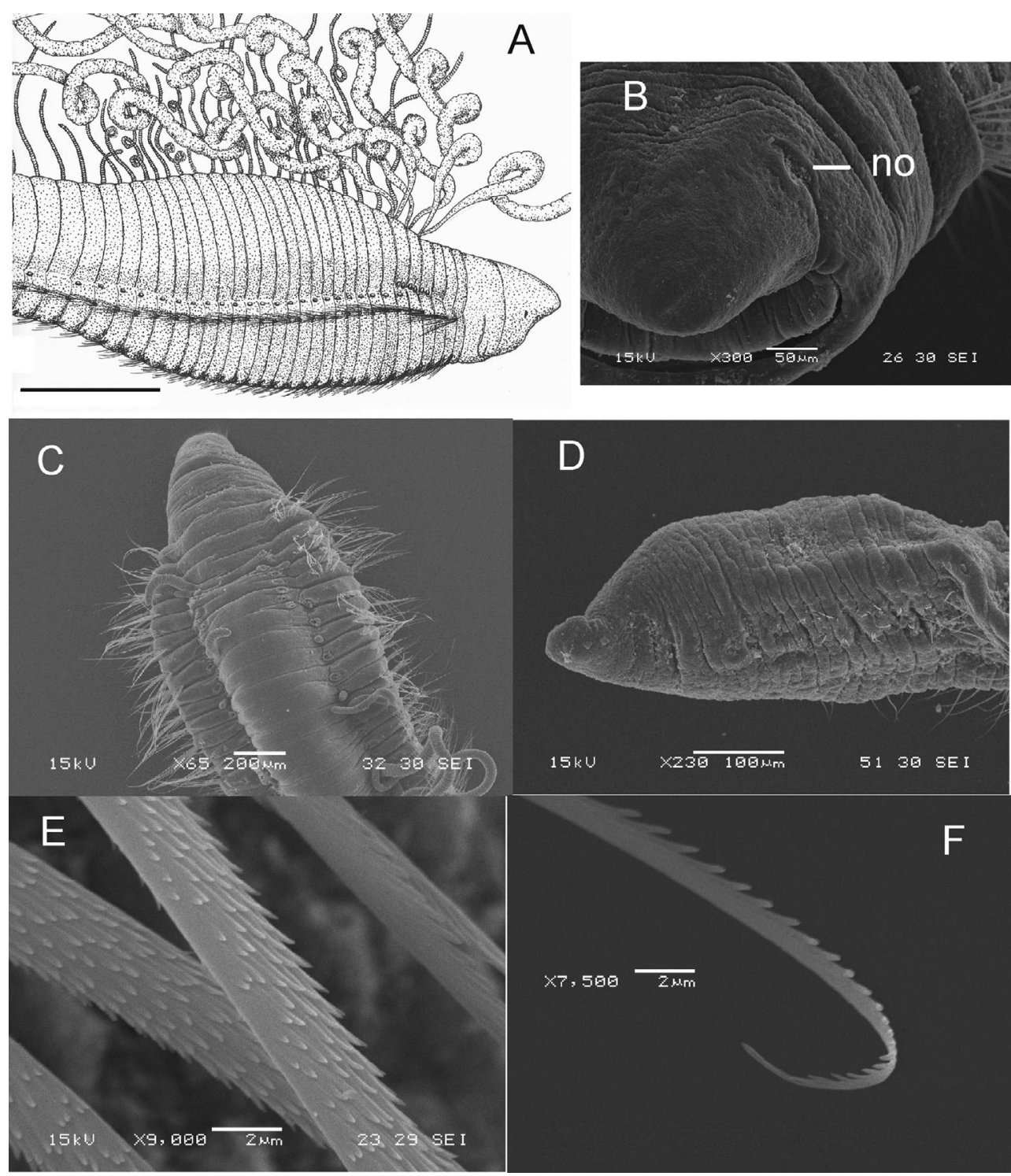

FIGURE 2. Protocirrineris angelicollatio sp. nov. A, general view of anterior part; B, SEM frontal photo showing nuchal organ; C, SEM dorsal view of anterior region; D, pygidium; E, SEM of capillary tip; F, SEM photo showing denticulation of capillaries. Scale bar: $\mathrm{A}=0.3 \mathrm{~mm}$. 
Parapodia forming well-developed shoulders in anterior region with segments crowded and narrow; first chaetigers and thoracic region wider than prostomium, appearing fusiform in dorsal view. Posterior segments also narrow, crowded but expanded laterally and dorsally. Pygidium simple lobe, anus dorsal.

Segments encompassed by dorsal dome frequently with narrow transverse subdivision posteriorly. Dome narrowest at chaetiger 4 due to height of anterior lateral shoulder; chaetiger 1 lowest, then increasing in height to chaetiger 4, thereafter decreasing again; superficially worm with an anterior dorsal hump (Fig. 2A). Dorsal tentacles, cirri gray or pale tan in life typically arising from chaetigers 4-7, rarely from 5-8; smallest juveniles with tentacles on chaetigers 3-6. In these segments dorsal dome divided in two or exceptionally three lobes before shoulders, each one bearing dorsal tentacle (Fig. 2A, C). Branchiae with minute annulations, first present from posteriormost tentacle-bearing chaetiger; branchiae arising in posterodorsal part of parapodial shoulders, continuing on subsequent segments to middle of body; branchiae large and more prominent in anterior one-third of the body, becoming shorter and thinner thereafter. Noto- and neuropodia widely separated from one another anteriorly, becoming closer in middle and posterior segments; each podial lobe bearing numerous long, smooth chaetae with approximately 16 capillaries in each fascicle anteriorly, then chaetae decreasing in posterior region in both number and length; prepygidial chaetigers with only two capillaries. Individual capillaries appearing smooth in light microscope, but with SEM at 7,500 x, capillaries with smooth bases, but becoming progressively covered with fine spinelets or teeth on one side of shaft, but with opposite side of shaft and tip smooth (Fig. 2E-F).

Methyl green staining pattern. The body stained uniformly dark green (perhaps due to the dark coloration of fixed material),

Habitat and behavior. The species is known from the Mar del Plata area. The worms inhabit the sediment in intertidal Brachidontes rodriguezii mussel beds, in organically enriched areas. Greatest densities were recorded at 50-200 m from the sewage outfall. Analyses showed that Protocirrineris angelicollatio sp. nov. is more abundant in the lower intertidal, before the summer season, and in impacted areas (Elias et al. 2006 as Cirratulus sp.).

Several fragments (9-10) of the head region and a few chaetigers were placed in aquaria with a little layer of sediment from the original habitat. After four months all fragments had regenerated completely, with the total population of the aquaria including more worms than the initial number of fragments. The living specimens accumulated the sediment into mounds that included a great number of diatoms. Every mound contained several specimens of P. angelicollatio sp. nov., recognized by the gray tentacles and red branchiae that emerged at the surface. The worms may also aggregate in a transparent mucus cocoon. Animals in placed in Petri dishes quickly shed branchiae and tentacles, which were almost as long as the body. This mass of filaments was covered in mucus, making manipulation difficult.

The intestinal tract was full of sedimentary particles, suggesting poor selection in feeding from subsurface sediments. Perhaps their gregarious behavior is a response to their rapid asexual reproduction. Several records of Protocirrineris from the area often correspond to dense monospecific patches in limestone crevices, including sand retained in mussel beds (Orensanz, unpublished data).

Remarks. Protocirrineris angelicollatio sp. nov. has a short prostomium, and a peristomium with two dorsolateral annulations and a third one visible ventrally, the last annulation anterior to chaetiger 1 is the widest and ventrally overlaps the others. Whereas, P. antarcticus Monro 1930 has a short prostomium and a long peristomium with two weakly distinguished annulations. In $P$. angelicollatio sp. nov. dorsal tentacles arise from lateral subdivisions of segments 4-7 in the dorsal 
dome. Two or (rarely) three pairs of dorsal tentacles arise very close to the shoulder from each segment. Branchiae also arise very close to shoulder in the back of the notopodium, beginning in the last chaetiger bearing tentacular filaments. In $P$. antarcticus dorsal tentacles arise between chaetigers 3-5 with 6-8 in each group, from expansions of the chaetigers (fig. 50 in Monro 1930). Protocirrineris angelicollatio sp. nov. differs from $P$. chrysoderma (Claparède, 1868) due to the presence of wide shoulders in our material; the origin of the first branchiae is in the first segment bearing tentacular cirri in $P$. chrysoderma but in the last segment in $P$. angelicollatio sp. nov.; branchial filaments are not stout in South American material. P. socialis Blake 1996 has a large peristomium, as long as the first 5-6 segments, with two annulations. Tentacular cirri arise above chaetigers 7-9 and are arranged in six longitudinal rows of 3-4 tentacles per row in large specimens, while small specimens have fewer filaments, arising from chaetigers 5-7. Branchiae are present from chaetigers 1-3 to the middle region, arising from a point just dorsal to the notosetal fascicle; the posterior region is not inflated. Distinct shoulders are present, especially in the thoracic region, where the worms are widest. $P$. socialis lives in dense populations in the rocky intertidal zone of central California.

Etymology. The species name is derived from angeli $=$ angel, collatio= meet or date. The species name is dedicated to the Cuban singer Silvio Rodriguez for his song "Cita con Angeles," which is a song about September 11 in Chile (1973) and the United States of America (2001) and other human atrocities.

\section{Discussion}

The genera Aphelochaeta and Protocirrineris have been reestablished recently by Blake (1991) and Petersen (1991), respectively. There are relatively few described species of both Aphelochaeta and Protocirrineris, most of them widely distributed. For example, $P$. chrysoderma has been reported from the Mediterranean Sea, India, and Japan, but also from several parts of the southern hemisphere, including South Africa, Brazil, and Chile. It is suspected that new revisions are need in this genus, because some species have a reported distribution extending over wide geographical areas.

On the other hand, the genus Aphelochaeta has been better studied and several species described. On the western coast of North America, 16 species of Aphelochaeta were discovered but only eight have been described (Blake 1996). One of the most difficult taxonomic problems is the identity of Aphelochaeta (= Heterocirrus) marioni St. Joseph, 1894, because it is possible that the wide records of the species, including records from South Africa, Chile, and Venezuela (Rozbaczylo et al. 2006) could be more than one species (Blake 1996: 331). However, the genus has not been reported from other parts of South America, although several species of Tharyx are present in Brazilian coasts (Amaral et al. 2006). The present paper is the first mention of the genus from Argentine waters.

The Mar del Plata area appears to be a "hot spot" for new species of cirratulids. Two new species of Caulleriella (Elías \& Rivero 2008) and the two new species herein described are only a small part of the available material. Intertidal material includes an undescribed species of Dodecaceria, while subtidal material includes a new species that needs to be assigned to a genus, several undescribed species from the Mar del Plata harbor, and others from the continental shelf. Before the beginning of the study of cirratulids, the ecological work in the area comprised only two species, Caulleriella alata and Cirratulus cirratus (Elías et al. 2003, 2006). The former, originally described from Ireland, and the second from European waters were not present on the Mar del Plata coast. The presence of C. alata and C. alata chilensis in Chile (Carrasco 1977) may also need revision. Dean (2004) 
mentioned that in Costa Rica an intensive analysis by modern workers may have revealed that what was originally considered a single species with a wide geographical distribution is actually two or more recognizable similar species. Blake (1996) suspected that widely distributed species are probably rare, and high numbers of endemic species of cirratulids are to be expected. This has been also the result of the discussion about coastal cosmopolitanism at the recent International Polychaete Conference (Maine, USA).

The Symposium on Latin American Polychaetes (Sao Sebastiao, Brazil, 2006) showed that the taxonomy of polychaetes in Latin America is far below the levels achieved in the northern hemisphere. This could be due to the lack of both specialists and extended surveys. A single study of the Pacific coast of Costa Rica showed five new species of Caulleriella and another five of Chaetozone (Dean \& Blake 2007). How many cirratulid species remain undiscovered in Latin America? Only extensive surveys by taxonomists can answer this question. This is central to our wise management of the coastal zone in order to protect and preserve biodiversity for future generations.

\section{Acknowledgements}

We would like to thank the following people who have assisted in various ways: Mary E. Petersen for her generous contributions (via e-mail), which provided insights into the subject; our colleagues Claudia Bremec (INIDEP-Mar del Plata), Lobo Orensanz (CenPat-Puerto Madryn), and Paulo Lana (UFPR — Curitiba) for providing bibliographic articles, ideas, and constructive comments. All have contributed to this and other manuscripts. Ana Claudia Brasil for the Grey \& Wess Medium formula. SEM images were obtained by Lic. Mónica Oppedisano from the Laboratorio de Microscopía Electrónica of Facultad de Ciencias Exactas y Naturales of the Universidad Nacional de Mar del Plata. Figures were drawn by R. E. The manuscript was kindly revised by Susan Chambers (Principal Curator of Marine Invertebrates, National Museums of Scotland, UK). Two reviewers greatly improved the manuscript. The project is supported by PICTO $2004 \mathrm{n}^{\circ} 1-536$ (BID 1728/OCAR) by the Universidad Nacional de Mar del Plata and the Agencia Nacional de Promoción de Ciencia y Técnica (ANPCyT - FONCyT).

\section{References}

Amaral, A.C.Z., Nallin S.A.H. \& Stainer T.M. (2006) Catalogo das Especies de Annelida Polychaeta do Brasil. http://www.ib.unicamp.br/destaqueslbiotalbentos marinhol prod_cien\ texto_poli.pdf (consulted in 2008).

Acha, E.M., Mianzan, H.W., Guerrero, R.A., Favero, M. \& Bava, J. (2004) Marine fronts at the continental shelves of austral South America. Physical and ecological processes. Journal of Marine Systems, 44, 83-105.

Blake, J.A. (1991) Revision of some genera and species of Cirratulidae (Polychaeta) from the western North Atlantic. Ophelia supplement 5, 17-30.

Blake, J.A. (1996) Family Cirratulidae Ryckholdt, 1851. Including a revision of the genera and species from the Eastern North Pacific. In: Blake J.A., Hilbig, B. \& Scott, P.H. (Eds.), Taxonomic Atlas of the Benthic Fauna of the Santa Maria Basin and Western Santa Barbara Channel. Volume 6. The Annelida Part 3 - Polychaeta: Orbiniidae to Cossuridae. Santa Barbara Museum of Natural History, Santa Barbara, California, pp. 27-70.

Boschi, E.E. (2000) Species of decapods crustaceans and their distribution in the American marine zoogeographic provinces. Instituto Nacional de Investigación y Desarrollo Pesquero, 13, 136 pp.

Carrasco, F.D. (1977) Polychaeta (Annelida) de Bahía de Concepción, Chile. Familias Orbiniidae, Cirratulidae, Cossuridae, Capitellidae y Ampharetidae, con la descripción de tres especies y una subespecie nuevas. Boletín Sociedad de Biología de Concepción, 51 (1), 67-92. 
Dean, H.K. (2004) Marine biodiversity of Costa Rica: Class Polychaeta (Annelida). Revista de Biología Tropical, 52 (suppl. 2), 131-181.

Dean, H.K. \& Blake, J.A. (2007) Chaetozone and Caulleriella (Polychaeta: Cirratulidae) from the Pacific Coast of Costa Rica, with description of eight new species. Zootaxa, 1451, 41-68.

Dean, H.K. \& Blake, J.A. (2009) Monticellina (Polychaeta: Cirratulidae) from the Pacific coast of Costa Rica with descriptions of six new species. Zoosymposia, 2, 105-126.

Doner, S.A. \& Blake, J.A. (2006) New species of Cirratulidae (Polychaeta) from the northeastern United States. Scientia Marina, 70 (S3), 65-73.

Doner, S.A. \& Blake, J.A. (2009) Two new species of Aphelochaeta (Polychaeta: Cirratulidae) from deep water off northern California. Zoosymposia, 2, 127-137.

Elías, R., Rivero, M.S. \& Vallarino, E.A. (2003) Sewage impact on the composition and distribution of Polychaeta associated to intertidal mussel beds of the Mar del Plata rocky shore, Argentina. Iheringia Serie Zoologia, 93 (3), 309-318.

Elías, R., Vallarino, E.A., Scagliola, M. \& Isla, F.I. (2004) Macrobenthic distribution patterns at a sewage disposal site in the inner shelf off Mar del Plata (SW Atlantic). Journal of Coastal Research, 20 (3), 1178-1182.

Elías, R., Palacios, J.R., Rivero, M.S. \& Vallarino, E.A. (2005) Short-term responses to sewage discharge and storms of subtidal sand-bottom macrozoobenthic assemblages off Mar del Plata City, Argentina (SW Atlantic). Journal of Sea Research, 53, 231-242.

Elías, R., Rivero M.S., Palacios, J.R. \& Vallarino, E.A. (2006) Sewage-induced disturbance on Polychaetes inhabiting intertidal mussel beds of Brachidontes rodriguezii off Mar del Plata (Southwestern Atlantic, Argentina). In: Scientific advances on Polychaete Rresearch). R. Sarda, San Martin, G., Lopez, E., Martin, D. \& George, D. (Eds.), Scientia Marina 70 (3): 187-196.

Elías, R. \& Rivero, M.S. (2008) Two new species of Caulleriella (Polychaeta: Cirratulidae) from Argentina. Iheringia, Serie Zoologia, 98 (2), 225-230.

Fauchald, K. (1977) The Polychaete Worms. Definitions and Keys to Orders, Families and Genera. Natural History Museum of Los Angeles County \& The Allan Hancock Foundation, University of Southern California, Science Series, 28, 1-188.

George, J.D. \& Petersen, M.E. (1991) The validity of the genus Zeppelina Valliant (Polychaeta: Ctenodrillidae). In: Petersen, M.E. \& Kirkegaard, J.B. (Eds.), Systematics, Biology and Morphology of World Polychaeta. Proceedings of the 2nd International Polychaeta Conference, Copenhagen, 1986. Ophelia supplement, 5, $89-100$.

Giangrande, A., Liccinao, M. \& Musco, L. (2005) Polychaeta as environmental indicators revisited. Marine Pollution Bulletin, 50, 1153-1162.

Monro, C.C.A. (1930) Polychaete worms. Discovery Reports, Cambridge, Volume 2, 1-222.

Orensanz, J.M. (1974). Los anélidos poliquetos de la Provincia Biogeográfica Magallánica. Catálogo de las especies citadas hasta 1974. Laboratorio de Comunidades Bentónicas - Gabinete abierto. Santa Clara del Mar, Contribución Técnica, 1, 3-76.

Petersen, M.E. (1991) A review of asexual reproduction in the Cirratulidae (Annelida: Polychaeta), with redescription of Cirratulus gaiheadius (Hartman, 1965), new combination, and emendation or reinstatement of some cirratulid genera. Bulletin of Marine Science, 48, 592 (Abstract).

Pocklington P. \& Wells, P.G. (1992) Polychaetes. Key taxa for marine environmental quality monitoring. Marine Pollution Bulletin, 24, 593-598.

Rozbaczylo, N., Moreno, R., Díaz-Díaz, O. \& Martinez, S. (2006) Benthic subtidal polychaetes on soft-bottoms of the Aysén region of Chile: Clade Terebellida (Annelida, Polychaeta). Ciencia y Tecnología del Mar, 29 (1), 71-90.

Rivero, M.S., Vallarino, E.A. \& Elías, R. (2005) First survey in the Mar del Plata Harbor (Argentina, $38^{\circ} 02^{\prime}$ S, $57^{\circ}$ $30^{\prime} \mathrm{W}$ ), and the use of polychaetes as potential indicators of pollution. Revista Biología Marina y Oceanografía, 40 (2), 101-108.

Vallarino, E.A., Rivero, M.S., Gravina, M.C. \& Elías, R. (2002) The community-level response to sewage impact in intertidal mussel beds of the Southwestern Atlantic, and the use of the Shannon index to assess pollution. Revista Biología Marina y Oceanografía, 37 (1), 25-33. 